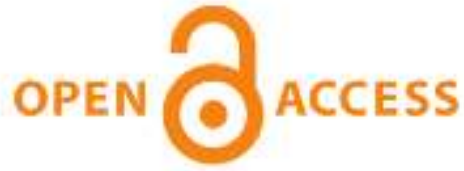

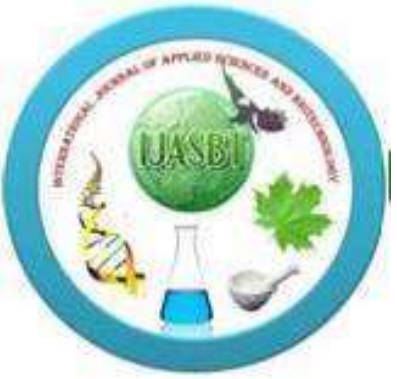 \\ International Journal of Applied Sciences and Biotechnology
}

A Rapid Publishing Journal

ISSN 2091-2609

\section{Indexing and Abstracting}

CrossRef, Google Scholar, Global Impact Factor, Genamics, Index Copernicus, Directory of Open Access Journals, WorldCat, Electronic Journals Library (EZB), Universitätsbibliothek Leipzig, Hamburg University, UTS (University of Technology, Sydney): Library, International Society of Universal Research in Sciences (EyeSource), Journal Seeker, WZB, Socolar, BioRes, Indian Science, Jadoun Science, JourInformatics, Journal Directory, JournalTOCs, Academic Journals Database, Journal Quality Evaluation Report, PDOAJ, Science Central, Journal Impact Factor, NewJour, Open Science Directory, Directory of Research Journals Indexing, Open Access Library, International Impact Factor Services, SciSeek, Cabell's Directories, Scientific Indexing Services, CiteFactor, UniSA Library, InfoBase Index, Infomine, Getinfo, Open Academic Journals Index, HINARI, etc.

\section{CODEN (Chemical Abstract Services, USA): IJASKD}

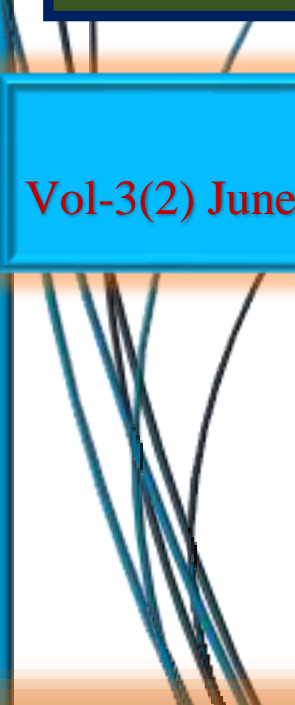

\section{Available online at:}

http://www.ijasbt.org

$\&$

http://www.nepjol.info/index.php/IJASBT/index

Impact factor*: $\mathbf{1 . 4 2 2}$

Scientific Journal Impact factor": $\mathbf{3 . 4 1 9}$

SEM-Biotech

Publishing

Index Copernicus Value: $\mathbf{6 . 0 2}$

*Impact factor is issued by Universal Impact Factor. Kindly note that this is not the IF of Journal Citation Report (JCR). "Impact factor is issued by SJIF INNO SPACE.

For any type of query and/or feedback don’t hesitate to email us at: editor.ijasbt@gmail.com 


\title{
SERO-PREVALENCE OF PORCINE REPRODUCTIVE AND RESPIRATORY SYNDROME (PRRS) IN PIGS OF DIFFERENT DEVELOPMENTAL REGIONS OF NEPAL
}

\author{
Mahesh K.C. . ${ }^{*}$, Bhoj Raj Joshi ${ }^{2}$, Swoyam Prakash Shrestha ${ }^{3}$, Meera Prajapati ${ }^{3}$, Dipak Kathayat ${ }^{1}$, Santosh Dhakal ${ }^{4}$
}

${ }^{1}$ Institute of Agriculture and Animal Science, Rampur Campus, Nepal

${ }^{2}$ National Animal Science and Research Institute, NARC, Khumaltar, Lalitpur, Nepal

${ }^{3}$ Animal Health Research Division, NARC, Khumaltar, Lalitpur, Nepal

${ }^{4}$ The Ohio State University, Columbus, USA

*Corresponding author's email: kcmahesh12@gmail.com

\begin{abstract}
Porcine reproductive and respiratory syndrome (PRRS) is a highly infectious viral disease of swine. This disease is becoming threat to pig industry of every corner of the world. As the status of this disease in Nepal is not properly understood so far, a cross-sectional sero-prevalence study was carried out in four development regions. A total of 200 blood samples were collected from major pig producing areas of eight districts of four development regions of Nepal and the serum samples were tested for antibodies against PRRS virus by rapid antibody detection kit (Immunochromatographic test using colloidal gold immunoassay: Schenzhen Lvshiyuan biotechnology Co. Ltd, China). Among the tested serum samples, 37 were found to be positive for PRRS indicating $18.5 \%$ prevalence of the disease. Statistically the prevalence difference was significant between different development regions and between topographical regions $(\mathrm{P}<0.05)$ of the country, but no significant difference was observed in age, sex and housing systems of pigs.

Presence of antibodies in serum against PRRSV in the unvaccinated pig population of the country clearly indicates that pigs of the surveyed regions of Nepal have already been exposed to PRRS virus and the disease should be given adequate attention during differential diagnosis of porcine respiratory diseases in Nepal. Further studies are needed for molecular characterization of the virus and to develop control strategies against this disease in the country.
\end{abstract}

Keywords: PRRS virus; Pig; Sero-prevalence; Nepal

\section{Introduction}

Porcine reproductive and respiratory syndrome (PRRS) is a highly infectious viral disease of swine. Globally, PRRS is an economically important disease of pigs and it causes over $\$ 664$ million loss in USA pork Industry alone (Batista et al. 2002; Lunney et al. 2010). It causes economically great loss in the swine industry worldwide through causing respiratory disease in neonatal pigs and reproductive failure in sows (Albina, 1997; Hopper, 1992; Neuman et al., 2005). This disease was first reported in North America in 1987, and now prevalent in almost all pig production areas of the World (Keffaber, 1989). A positive-stranded RNA virus belonging to Arteriviridae family, PRRS virus (PRRSV), is responsible to cause PRRS (Balasuriya et al., 2008; Zimmerman et al., 2006). This Virus has been manifested as constantly changing virus, representing very big challenge for controlling this disease (Kapur et al., 1996; Nelsen et al., 1999). There are broadly two genotypes of this virus, the European (type I) and the North American (type II) (Ellingson, 2010; Wensvoort et al., 1992). However, the symptoms of these two genotypes are similar and the genomes are diverging by only 40\% (Cavenagh, 1997).
Each genotype contains genetically diverse several subtypes and strains which differ in the virulence and pathogenicity in the herds (Kim et al., 2007). This disease has been named differently as porcine endemic abortion reproductive syndrome (PEARS), blue ears disease, mystery swine disease, swine infertility and respiratory syndrome, swine reproductive failure syndrome (Cesar et al., 2010).Pigs of any age are known to be the only known host of the PRRS (Albina, 1997). This syndrome can manifest in two forms, respiratory and reproductive form (OIE general information sheet). In respiratory disease the signs include, pneumonia, reduced food consumption, debilitation, chronic recurring illness and often high mortality. In reproductive form, poor sow performance will be evident with signs like return to estrous, premature farrowing, abortion, still birth and high pre-weaning mortality of piglets (Wensvoort, 1993).PRRSV is transmitted through direct and indirect contacts from infected pigs or even vertically to fetuses (Jenny et al., 2006). Virus is excreted in various body secretions including saliva, nasal secretion, urine, semen, milk, and colostrums (Wills et al., 1997; Yoon et al., 1993). 
PRRSV can spread by transport vehicles, farm supplies, personal attires, insects, fomites etc. to long distance as well (Otake, 2002; Report adhoc, 2008 ). Infected pig sheds PRRSV in feces for 7 days and it can persist in herds for years (Stevenson et al., 1994; Terpstra, 1991). The virus is persistent in infected pigs and remains in low levels within the animals but eventually decreases as the time passes on. As, PRRS is listed in the OIE "Terrestrial Animal Health Code" so all the OIE Members are obliged to report outbreaks to the OIE according to the OIE Terrestrial Animal Health Code (OIE general inform. sheet).Vaccination against this disease has been done with the use of live and dead vaccines in order to provide immunity to pigs against the PRRSV. Similarly, other management factors such as pig herd management, introduction of properly developed gilt and proper implementation of bio-security measures in the pig farm have been implied in order to protect pigs from the disease (Dee et al., 1996; Fano et al., 2005). In Nepal, previously PRRS was relatively unknown disease but in last few years several cases of PRRS has been suspected (Prajapati, 2013). Among its two neighboring countries, China pig industry has already been badly affected with this disease (Li et al., 2007; Zhang et al., 2007) while there are some reports of PRRS outbreak in India as well (www.pigsite.com). One study conducted in 2011, Sharma has shown 29\% seropositivity in samples collected from Kathmandu (Sharma, 2011). However, the geographical distribution of this disease and its economic impact in swine industry of Nepal is unknown. So, this study was conducted with the aim of determining the status of PRRSV infection in pigs raised at different geographical regions of Nepal.

\section{Materials and Methods}

\section{Study area}

This cross-sectional study was conducted from February to May, 2014 in the eight districts of four development regions of Nepal viz. Dhankuta, Sunsari, Chitwan, Kathmandu valley, Kaski, Rupandehi, Banke and Surkhet. These districts were selected because pig industry is growing rapidly in these areas and there is huge movement of pigs from these areas to rest of Nepal.

\section{Questionnaire and survey}

First of all a set of questionnaire was developed in order to get basic information about i) pig raising ii) housing management iii) health status and iv) vaccination information. Samples were collected in such a manner that it represented the whole district.

\section{Sample collection}

A total of 200 blood samples were collected from major pig producing areas of eight districts of four developmental regions of Nepal. Blood was collected from Radial vein using aseptic technique; centrifuged at 1000 RPM for 3 minutes and serum separated. Separated serum was transported to virology laboratory of Animal Health Research Division, NARC, Khumaltar, Lalitpur in ice cooled box for further laboratory test.

\section{Tests and testing procedure}

The serum samples were tested for the presence of PRRS antibody by using Colloidal Gold Immunechromatographic Cards manufactured by Schenzhen Lvshiyuan biotechnology Co. Ltd, China as per manufacturer's instructions. The test was aimed for detection of antibody (European and American strain) against porcine reproductive and respiratory syndrome. Briefly, 100ul of serum sample was added into the well on the test card. The test card was placed on the flat table, incubated for 5-20 minutes, and then result was recorded. Interpretation was carried out as, (i) Positive if control line and test lines were both seen as wine red, the more the antibody thicker the color appeared; (ii) Weak positive if control line and test line were both seen as light wine red; (iii) Negative: only control line was seen wine red and (iv) Invalidation if control line isn't seen wine red.

\section{Statistical analysis}

Data entry and data analysis was done by SPSS version 16.0 and association of different variables were analyzed by chisquare test with significance level defined at the level of $\mathrm{P}<0.05$. Graphical representation and tabulation was done in MS excel- 2007.

\section{Results}

Out of 200 serum samples tested, 37 serum samples were found to be positive with PRRS antibody detection kit. It shows $18.5 \%$ incidence of the disease in this study. According to the kit statement among positive samples, 21 serum samples were found to be strong positive, and 16 serum samples were found to be weak positive.

There was significant association between different development regions $(\mathrm{P}<0.05)$ and PRRS prevalence. Prevalence of PRRS was seen higher $(32 \%)$ in western development region and least $(6 \%)$ in eastern development region (table 1). Moreover, among 8 different districts Rupandehi district has higher prevalence (48\%), whereas no samples were positive from Dhankuta district.

The research was carried out in four districts of Terai region- Sunsari, Chitwan, Rupandehi and Banke, and four districts of Hilly region namely, Dhankuta, Kathmandu, Kaski, and Surkhet. Among them 25\% (25/100) serum samples were found to be positive in Terai region and $12 \%$ $(12 / 100)$ serum samples were found to be positive from the serum samples of Hill region. There was significant association between topography and PRRS prevalence $(\mathrm{P}<$ 0.05), Terai region having more prevalence than hills. 
M. K.C. et al. (2015) Int J Appl Sci Biotechnol, Vol 3(2): 218-222

Table 1: Total distribution of serum samples and sero-positivity status

\begin{tabular}{|c|c|c|c|c|c|}
\hline \multirow{2}{*}{\multicolumn{2}{|c|}{ Parameters }} & \multirow{3}{*}{$\begin{array}{l}\text { Sample number } \\
50\end{array}$} & \multicolumn{2}{|c|}{ Result } & \multirow{2}{*}{$P$ value } \\
\hline & & & Positive & Negative & \\
\hline \multirow{4}{*}{ Development Regions } & Eastern & & $3(6)$ & $47(94)$ & \multirow{4}{*}{0.006} \\
\hline & Central & 50 & $11(22)$ & $39(78)$ & \\
\hline & Western & 50 & $16(32)$ & $34(68)$ & \\
\hline & Mid-Western & 50 & $7(14)$ & $43(86)$ & \\
\hline \multirow{8}{*}{ Districts } & Sunsari & 25 & $3(12)$ & $22(88)$ & \multirow{8}{*}{ ND } \\
\hline & Dhankuta & 25 & 0 & 25 & \\
\hline & Kathmandu valley & 25 & $6(24)$ & $19(76)$ & \\
\hline & Chitwan & 25 & $5(20)$ & $20(80)$ & \\
\hline & Kaski & 25 & $4(16)$ & $21(84)$ & \\
\hline & Rupandehi & 25 & $12(48)$ & $13(52)$ & \\
\hline & Surkhet & 25 & $2(8)$ & $23(92)$ & \\
\hline & Banke & 25 & $5(20)$ & $20(80)$ & \\
\hline \multirow{2}{*}{ Topography } & Terai & 100 & $25(25)$ & $75(75)$ & \multirow{2}{*}{0.018} \\
\hline & Hill & 100 & $12(12)$ & $88(88)$ & \\
\hline \multirow{2}{*}{ Age } & Below 6 month & 60 & $9(15)$ & $51(85)$ & \multirow{2}{*}{0.404} \\
\hline & Above 6 month & 140 & $28(20)$ & $112(80)$ & \\
\hline \multirow{2}{*}{ Sex } & Male & 80 & $14(17.5)$ & $66(82.5)$ & \multirow{2}{*}{0.766} \\
\hline & Female & 120 & $23(19.2)$ & $97(80.8)$ & \\
\hline \multirow{3}{*}{ Housing System } & Intensive & 157 & $32(20.4)$ & $125(79.6)$ & \multirow{3}{*}{0.369} \\
\hline & Semi-intensive & 14 & $1(7.1)$ & 13(92.9) & \\
\hline & Free ranging & 29 & $4(13.8)$ & $25(86.2)$ & \\
\hline
\end{tabular}

\section{*ND: Not determined}

Similarly, serum samples of two age groups, below 6 month and above 6 month age of pig, were included in the research and it was found that $15 \%(9 / 60)$ serum sample of age below 6 month were found to be sero-positive and 20\% (28/140) serum samples of above 6 month were found to be positive in the test. In relation to sex-wise prevalence of PRRS in the result it was found that, $17.5 \%$ (14/80) serum samples of male pigs and $19.2 \%(23 / 120)$ serum samples of female pigs were positive(table 1).

The serum samples were collected from pigs reared in 3 different housing systems in order to find any significant difference in the prevalence of PRRS. Higher prevalence was seen in intensive system being 20.4\% (32/157) followed by in free ranging system $13.8 \%$ (4/29) and semiintensive system $7.1 \%(1 / 14)$.

\section{Discussion}

This study shows there is presence of antibodies against PRRS in the serum samples of pigs of different regions of Nepal. This result signifies that these animals must have been exposed to PRRSV in any time of their life span as vaccination against this disease is not practiced in Nepal and hence possibility of antibodies production through vaccination is completely ruled out.

The sero-prevalence found in this study i.e. $18.5 \%$, is less than the findings of Sharma (2011), where prevalence rate was found to be $29 \%$ in Kathmandu district. The geographical variation, sample collection time, test procedures etc. can be responsible for the differences in prevalence. However, in support of Sharma (2011) our study also confirms that PRRS virus is infecting pigs of Nepal and spreading to many regions. Regarding PRRS status in other countries, there was prevalence of $32.6 \%$ of PRRS antibody sero-positive samples in pigs of Thailand which is quite higher than this study (Tummaruk et al., 2013). According to Montagnaro et al., 37.7\% (129/342) sero-positive samples were found for PRRS in wild boars in Campania, southern Italy which is also very much higher than our finding (Montagnaro et al., 2010). According to Foti et al., (2008), 31.1\% sero-positive samples were found in the ELISA test during a serological survey of detecting PRRSV infection in Italian pigs (Foti et al., 2008).

Results show that there is high prevalence $(32 \%)$ of the disease in western development region and least (6\%) in eastern development region. Statistically significant difference $(\mathrm{P}<0.05)$ was observed between the development regions having high prevalence in western development region which might be due to the high movement of pigs and population from India to this region. According to district wise distribution Rupandehi district shows highest (48\%) prevalence and but Dhankuta district does not show any positive serum samples of PRRS.

Furthermore, $25 \%$ of the positive serum samples were from Terai districts and 12\% from the hill districts. The result shows that there is significant difference $(\mathrm{P}<0.05)$ between prevalence of disease in Terai and hilly region. This might be due to having maximum pig industry and huge movement of pigs in this area and also the nearby association of the Terai district with the Indian border.

Age wise, there is high prevalence i.e. $20 \%$ (28/140) in more than 6 month old pigs than pigs less than 6 month age i.e. $15 \%$ (9/60). Similarly, 19.2\% (23/120) female serum samples were positive than $17.5 \%(14 / 80)$ of male serum samples. The study shows $20.4 \%$ prevalence of disease in pigs rearing in intensive housing system where as only $13.8 \%$ and $7.1 \%$ in free ranging and semi intensive housing system respectively. So, except development region and 
topographical difference, there are no significant differences between other variables which signify that pigs of any sex, age, and housing system can be affected with this disease.

\section{Conclusions}

The presence of antibodies in the serum and the fact that there had been no vaccination against this disease in the country clearly indicates that the pigs of different development regions of Nepal had already been exposed to the PRRS virus. As there is no vaccination practices in the country, the positive result refers to natural infection. The result shows that PRRS is circulating in pigs of different developmental regions of Nepal, though in different proportion. Results show that there is high prevalence of disease in Terai than in hills. This might be due to the nearness of these places with the Indian border. Sharing borders with limited restrictions and poor quarantines might be transporting PRRS virus from one direction to other in these countries but research on PRRS is limited on both sides. This result also gives us clue that this is mostly localized in Terai district and pigs of hilly area are not severely affected yet. The high presence of positive case in Kathmandu valley might also be due to supply of pigs from Terai region to the valley.

PRRSV affects pigs irrespective of age, sex and breed. So, all pigs are at risk of PRRSV. It affects pigs irrespective of housing system. Though mountain region is not included in this study, the Terai and Hill districts showing sero-positive pigs for PRRSV indicates the presence of virus in most part of the country. All these circumstances suggest for further detailed study on this disease and its economic impact in pig industry of Nepal to develop suitable control measures against this disease.

\section{Acknowledgements}

This research was funded by Zoonosis Control Project under National Animal Science Research Institute, Nepal Agriculture Research Council, Nepal. Likewise, we are immensely grateful to all the farmers for cooperating us in the field during sample collection. Similarly, we are also very much thankful to all the helping hands for their contributions in different ways and means.

\section{Conflict of interest: None}

\section{References}

Albina E (1997) Epidemiology of porcine reproductive and respiratory syndrome (PRRS): An overview. Vet. Microbio. 55(1-4): 309-316

Balasuriya and Snijder. (2008) "Arteriviruses". Animal Viruses: Molecular Biology. Caister Academic Press. ISBN 978-1$\underline{904455-22-6}$

Batista L, Dee SA, Rossow KD, Deen $\mathrm{J}$ and Pijoan $\mathrm{C}$ (2002)Assessing the duration of persistence and shedding of porcine reproductive and respiratory syndrome virus in a large population of breeding-age gilts. Can. J. Vet. Res. 66(3): 196-200.

Cavenagh D (1997) Nidovirales: A new order comprising Coronaviridae and Arteriviridae. Arch. Virol . 142: 629633

Cho JG and Dee SA (2006) Porcine reproductive and respiratory syndrome virus. Therio genology 66: 655-662.

Corzo CA, Mondaca E, Wayne S, Torremorell M, Dee S , Davies $\mathrm{P}$ and Morrison RB (2010) A review on control and elimination of porcine reproductive and respiratory syndrome. Virus research 154: 185-192.

Dee SA, Joo HS, Henry S, Tokach L, Park BK, Molitor TW, et al. (1996) Detecting subpopulations after PRRS virus infection in large breeding herds using multiple serologic test. Swine Health Prod. 4: 181-184.

Ellingson, JS, Wang Y, Layton S, J. Ciacci-Zanella, Roof MB, and Faaberg KS (2010) Vaccine efficacy of porcine reproductive and respiratory syndrome virus chimeras. Vaccine 28: 2679-2686.

Fano E, Olea L and Pijoan C (2005) Eradication of porcine reproductive and respiratory syndrome virus by serum inoculation of naive gilts. Can. J. Vet. Res. 69:71-74.

Foti M, Bottari T, Daidone A, Rinaldo D, De Leo F, Foti S, and Giacopello C (2008) Serological survey on Aujeszky's disease, swine influenza and porcine reproductive and respiratory syndrome virus infections in Italian pigs. Pol. J. Vet. Sci. 11(4): 323-325.

Hopper SA, White ME and Twiddy N (1992) An outbreak of blueeared pig disease (porcine reproductive and respiratory syndrome) in four pig herds in Great Britain. Vet. Rec. 131: 140-144.

Kapur V, Elam MR, Pawlovich TM and Murtaugh MP (1996) Genetic variation in porcine reproductive and respiratory syndrome virus isolates in the Midwestern United States. J. Gen. Virol. 77(6): 1271-1276.

Keffaber K (1989) Reproductive failure of unknown etiology. American Association of swine Practitioners Newsletter 1: $1-19$.

Kim WI, Lee DS, Johnson W, Roof M, Cha SH and Yoon KJ (2007) Effect of genotypic and biotypic differences among PRRS viruses on the serologic assessment of pigs for virus infection. Vet. Microbiol. 123: 1-14.

Li Y et al. (2007) Emergence of a highly pathogenic porcine reproductive and respiratory syndrome virus in the MidEastern region of China. Vet. J. 174: 577-584.

Lunney JK, Benfield DA and Rowland RR (2010) Porcine reproductive and respiratory syndrome virus: an update on an emerging and re-emerging viral disease of swine. Virus Res. 154: 1-6.

Montagnaro S, Sasso S, De Martino L, Longo M, Oovane V, Ghiurmino G, Pisanelli G, Baldi L and Paqnini U (2010) Prevalence of antibodies to selected viral and bacterial pathogens in wild boar (Sus scrofa) in Campania Region, Italy. J. wild disease. 46(1): 316-319. 
Nelsen CJ, Murtaugh MP and Faaberg KS (1999) Porcine reproductive and respiratory syndrome virus comparison: divergent evolution of two continents. J. Virol. 72: 270280 .

Neumann EJ, Kliebenstein JB, Johnson CD, Mabry JW, Bush EJ, Seitzinger AH, Green AL and Zimmerman JJ (2005) Assessment of the economic impact of porcine reproductive and respiratory syndrome on swine production in the United States. J. Am. Vet. Med. Assoc. 227: 385-392.

OIE. PRRS. General information sheet

Otake S, Dee SA, Rossow KD, et al. (2002) Transmission of porcine reproductive and respiratory syndrome virus by needles. Vet. Rec. 150: 114-115.

Prajapati, M (2013) Outbreak of Porcine Reproductive and Respiratory Syndrome in Khumaltar farm: A case report.

Report of the OIE Ad hoc group on porcine reproductive respiratory syndrome Paris, 9-11 June 2008.

Sharma B (2011) A Survey for Porcine Respiratory and Reproductive Syndrome (PRRS) in Pigs of Kathmandu Valley of Nepal. Technical Report 2067-68 B.S. Directorate of Animal Health Nepal. pp 38-41.

Stevenson GW, Van Alstine WG and Kanitz CL (1994) Characterization of infection with endemic porcine reproductive and respiratory syndrome virus in a swine herd. Journal of the American Veterinary Medical Association 204: 1938-1942.

Terpstra C, Wensvoort G and Pol JMA (1991) Experimental reproduction of porcine epidemic abortion and respiratory syndrome (mystery swine disease) by infection with Lelystad virus: Koch's postulates fulfilled. Veterinary Quarterly 13: 131-136.
Tummaruk P, Surapat P, Sriariyakun S, Seemakram O, Olanratmanee EO, Tantilertcharoen R, Thanawonqnuwech R (2013) Porcine reproductive and respiratory syndrome virus detection in Thailand during 2005-2010 in relation to clinical problems, Pig types, regions, and seasons. Trop. Anima. health prod. 45(3): $771-779 \ldots$.

Wensvoort G (1993) Lelystad virus and the porcine epidemic abortion and respiratory syndrome. Veterinary Research 24: 117-124.

Wensvoort G, De Kluyver EP, Luijtze EA, Den Besten A, Harris L, Collins JE, Christianson WT and Chladek C. (1992) Antigenic comparison of Lelystad virus and swine infertility and respiratory syndrome (SIRS) virus. Journal of Veterinary Diagnostic Investigation. 4: 134-138.

Wills RW, Zimmerman JJ, Yoon KJ, Swenson SL, Hoffman LJ, McGinely MJ, et al. (1997) Porcine reproductive and respiratory syndrome virus: routes of excretion. Vet. Microbiol. 57: 69-81.

Yoon IJ, Joo HS, Christianson WT, Morrison RB and Dial GD (1993) Persistent and contact infection in nursery pigs experimentally infected with porcine reproductive and respiratory syndrome (PRRS) virus. Swine Health Prod. 1: $5-8$.

Zhang L, Tian X and Zhou F (2007) Intranasal administration of $\mathrm{CpG}$ oligonucleotides induces mucosal and systemic Type 1 immune responses and adjuvant activity to porcine reproductive and respiratory syndrome killed virus vaccine in piglets in vivo. Int. Immuno-pharmacol 7: 1732-1740.

Zimmerman J, Benfi eld D, Murtaugh M, Osorio F, Stevenson G, and Torremorell M (2006) Porcine reproductive and respiratory syndrome virus. Diseases of Swine (9th edition). 